15. Xenoulis, P.G., Lopinski, D.J., Read, S.A., Suchodolski, J.S., \& Steiner, J.M. (2013). Intestinal Tritrichomonas foetus infection in cats: a retrospective study of 104 cases. J Feline Med Surg, 15, 1098-1103. doi: 10.1177/1098612X13495024.

16. Mardell, E.J., \& Sparkes, A.H. (2006). Chronic diarrhoea associated with Tritrichomonas foetus infection in a British cat. Vet Rec, 158, 765-766. doi: 10.1136/vr.158.22.765.

17. Stockdale, H., Rodning, S., Givens, M., Carpenter, D., Lenz, S., Spencer, J. et al. (2007). Experimental infection of cattle with a feline isolate of Tritrichomonas foetus. J Parasitol, 93, 1429-1434. doi: 10.1645/GE-1305.1.

18. Foster, D.M., Gookin, J.L., Poore, M.F., Stebbins, M.E., \& Levy, M.G. (2004). Outcome of cats with diarrhea and Tritrichomonas foetus infection. $J$ Am Vet Med Assoc., 225, 888892. doi: 10.2460/javma.2004.225.888.

\title{
УДК 636.09:504:621.039.574.5:[637+635+634+636/085](477)
}

DOI: $10.31073 /$ vet_biotech34-15

ПРОКОПЕНКО Т.О., e-mail: progresscentrlabvet@gmail.com МАЛІМОН 3.В., e-mail: z_malimon@ukr.net ГУСАК Л.М., e-mail: lgusak@ @igmir.net МОЛОДИК А.Г., e-mail: anghelikamolodyk@ gmail.com Державний науково-дослідний інститут з лабораторної діагностики та ветеринарно-санітарної експертизи

\section{ОЦІНКА РЕЗУЛЬТАТІВ ДОСЛІДЖЕННЯ РАДІАЦІЙНОӤ ЗАБРУДНЕНОСТІ ХАРЧОВИХ ПРОДУКТІВ ТА КОРМІВ 3А 2013-2017 РОКИ}

Здійснено аналіз результатів досліджень радіоактивного забруднення харчових продуктів та кормів, щзо були виконані державними лабораторіями Держпродспоживслужби в Україні за період 2013-2017 рр. Визначено критичні дозоутворюючі харчові продукти молоко ВРХ та дари лісу. Встановлено, що роль у формуванні дози внутрішнього опромінення належить ${ }^{137}$ Cs. Проаналізовано динаміку забруднення молока ВРX 32000 по 2017 роки. Найбільи неблагополучними за вмістом ${ }^{137}$ Cs в молочі є Житомирська, Волинська і Рівненська області. Київька, Чернігівська області - відносно чисті по молоку. Вивчено результати досліджень щздо вмісту ${ }^{137}$ Cs в харчових продуктах та кормах у Житомирській області.

Ключові слова: радіологічний контроль, динаміка забруднення, радіоізотопи, харчові продукти, корми.

Вступ. Забезпеченість населення безпечними та екологічно чистими продуктами харчування була і залишається загальнодержавною проблемою України, що потребує першочергового вирішення [1].

Ветеринарний радіологічний контроль є одним із видів радіоекологічного моніторингу навколишнього середовища. Відповідно до чинних в Україні нормативно-правових актів державними лабораторіями Держпродспоживслужби України здійснюється радіологічний контроль та моніторинг за безпечністю продукції щодо вмісту радіонуклідів, яка йде на експорт, ввозиться по імпорту, а також реалізується на ринках [2]. Оскільки найбільш біологічно значимими забруднювачами у випадку аварії у відновлюваний період $\epsilon{ }^{137} \mathrm{Cs}$ та ${ }^{90} \mathrm{Sr}$, система ветеринарного радіологічного контролю спрямована на визначення саме цих показників.

Мета роботи. Аналіз даних, накопичених при довгостроковому систематичному дослідженні на вміст радіоізотопів харчових продуктів та кормів. Проаналізувати радіаційну ситуацію в областях України стосовно харчових продуктів та кормів за період з 2013 по 2017 роки. Визначити 
критичні дозоутворюючі харчові продукти. Вивчити динаміку забрудненості критичних дозоутворюючих харчових продуктів.

Матеріали та методи: загальноприйняті статистично-аналітичні методи, звітність радіологічних відділів лабораторій Держпродспоживслужби України, $\gamma-\beta$ - спектрометричний метод визначення вмісту радіонуклідів.

Результати досліджень та їх обговорення. Здійснено аналіз результатів радіоактивного забруднення харчових продуктів та кормів в Україні за період 2013-2017 pp.

При цьому встановлено, що за цей період лабораторіями Держпродспоживслужби України було проведено 8627385 досліджень зразків харчових продуктів та кормів на вміст ${ }^{137} \mathrm{Cs}$ та ${ }^{90} \mathrm{Sr}$. У 2897 зразках виявлено перевищення максимально допустимого рівня (далі - МДР) ${ }^{137} \mathrm{Cs}(2887),{ }^{90} \mathrm{Sr}$ (10).

Докладніше інформацію щодо зафіксованих перевищень МДР вмісту радіонуклідів та значення питомої активності по видам продукції за період 2013-2017 років наведено у таблиці 1.

Таблиия 1

Результати досліджень щодо визначення вмісту радіонуклідів ${ }^{137} \mathrm{Cs}$ Ta ${ }^{90} \mathrm{Sr}$ в харчових продуктах та кормах за період 2013-2017 pp.

\begin{tabular}{|c|c|c|c|c|c|}
\hline $\begin{array}{c}\text { Вид } \\
\text { продукції }\end{array}$ & $\begin{array}{c}\text { Назва } \\
\text { областей, де } \\
\text { виявлено } \\
\text { перевищення } \\
\text { вмісту } \\
\text { радіонуклідів }\end{array}$ & $\begin{array}{c}\text { Кількість проб, } \\
\text { в яких вміст } \\
\text { радіонуклідів } \\
\text { перевищус } \\
\text { допустимі рівні } \\
\text { Cs-137/ Sr-90 }\end{array}$ & $\begin{array}{c}\text { Допустимий } \\
\text { рівень } \\
\text { Cs-137/ Sr-90 } \\
\text { Бк/кг }\end{array}$ & $\begin{array}{c}\text { Питома } \\
\text { активність } \\
\text { Сs-137, } \\
\text { (min-max), } \\
\text { Бк/кГ }\end{array}$ & $\begin{array}{c}\text { Питома } \\
\text { активність } \\
\mathrm{Sr}-90, \\
\text { (min-max), } \\
\text { Бк/кг }\end{array}$ \\
\hline 1 & 2 & 3 & 4 & 5 & 6 \\
\hline \multirow[t]{4}{*}{ Молоко } & Всього: & 624/- & $100 / 20$ & & \\
\hline & Волинська & 34 & & $115,6-134,7$ & - \\
\hline & Житомирська & 457 & & $101,0-725,0$ & - \\
\hline & Рівненська & 133 & & $101,0-919,0$ & - \\
\hline \multirow[t]{4}{*}{ М'ясо ВРХ } & Всього: & $23 /-$ & $200 / 20$ & & \\
\hline & Волинська & 13 & & $221,3-240,6$ & - \\
\hline & Житомирська & 7 & & $211,0-795,0$ & - \\
\hline & Рівненська & 3 & & $206,0-256,0$ & - \\
\hline \multirow[t]{5}{*}{$\begin{array}{c}\text { М'ясо диких } \\
\text { тварин }\end{array}$} & Всього: & $335 /-$ & $400 / 40$ & & \\
\hline & Волинська & 8 & & $\begin{array}{l}416,4- \\
2356,0\end{array}$ & \\
\hline & Житомирська & 207 & & $\begin{array}{c}405,2- \\
51455,0\end{array}$ & - \\
\hline & Київська & 74 & & $\begin{array}{l}446,3- \\
5870,8\end{array}$ & - \\
\hline & Рівненська & 46 & & $\begin{array}{l}439,0- \\
5271,0\end{array}$ & - \\
\hline
\end{tabular}


Продовження таблиці 1

\begin{tabular}{|c|c|c|c|c|c|}
\hline 1 & 2 & 3 & 4 & 5 & 6 \\
\hline Риба свіжа & Всього: & $8 /-$ & $130 / 35$ & & \\
\hline & Житомирська & 7 & & $162,0-847,0$ & - \\
\hline & Київська & 1 & & 185,0 & - \\
\hline \multirow[t]{14}{*}{$\begin{array}{c}\text { Гриби та } \\
\text { ягоди свіжі }\end{array}$} & Всього: & $1191 /-$ & $500 / 50$ & & \\
\hline & Вінницька & 2 & & $\begin{array}{l}589,0- \\
3353,0\end{array}$ & - \\
\hline & Волинська & 53 & & $\begin{array}{l}976,6- \\
2044,0\end{array}$ & - \\
\hline & Житомирська & 736 & & $\begin{array}{c}503,0- \\
15520,0\end{array}$ & - \\
\hline & Київська & 167 & & $\begin{array}{l}513,0- \\
2759,0\end{array}$ & - \\
\hline & Львівська & 7 & & $580,5-821,5$ & - \\
\hline & Полтавська & 1 & & 1042,0 & - \\
\hline & Рівненська & 86 & & $\begin{array}{l}510,0- \\
4382,0\end{array}$ & - \\
\hline & Сумська & 106 & & $\begin{array}{l}505,0- \\
2965,8\end{array}$ & - \\
\hline & Черкаська & 13 & & $619,0-841,0$ & - \\
\hline & Чернігівська & 16 & & $\begin{array}{c}564,0- \\
10031,0\end{array}$ & - \\
\hline & Донецька & 1 & & 3003,3 & - \\
\hline & Закарпатська & 2 & & $\begin{array}{l}3203,0- \\
31880,0\end{array}$ & - \\
\hline & Миколаївська & 1 & & 2522,0 & - \\
\hline \multirow[t]{9}{*}{$\begin{array}{c}\text { Гриби та } \\
\text { ягоди сухі }\end{array}$} & Всього: & $533 /-$ & $2500 / 250$ & & \\
\hline & Вінницька & 1 & & 3426,0 & - \\
\hline & Волинська & 214 & & $\begin{array}{l}2868,0- \\
16280,0\end{array}$ & - \\
\hline & Житомирська & 242 & & $\begin{array}{l}2518,0- \\
65320,0\end{array}$ & - \\
\hline & Київська & 5 & & $\begin{array}{l}3278,0- \\
13800,0\end{array}$ & - \\
\hline & Львівська & 1 & & 9919,0 & - \\
\hline & Рівненська & 33 & & $\begin{array}{l}2610,0- \\
24950,0\end{array}$ & - \\
\hline & Сумська & 16 & & $\begin{array}{l}2603,3- \\
10356,6\end{array}$ & - \\
\hline & Чернігівська & 21 & & $\begin{array}{l}2666,0- \\
28580,0\end{array}$ & - \\
\hline \multirow[t]{2}{*}{ Мед } & Всього: & $16 /-$ & $200 / 50$ & & \\
\hline & Житомирська & 16 & & $250,0-864,0$ & - \\
\hline \multirow[t]{3}{*}{$\begin{array}{c}\text { Овочі свіжі, } \\
\text { зелень }\end{array}$} & Всього: & $102 /-$ & $40 / 20$ & & \\
\hline & Житомирська & 1 & & 138,0 & - \\
\hline & Сумська & 101 & & $41,6-103,3$ & - \\
\hline
\end{tabular}




\begin{tabular}{|c|c|c|c|c|c|}
\hline & & & & \multicolumn{2}{|c|}{ Продовження таблииі 1} \\
\hline 1 & 2 & 3 & 4 & 5 & 6 \\
\hline $\begin{array}{l}\text { Лікарська } \\
\text { сировина }\end{array}$ & Всього: & $13 / 2$ & $200 / 100$ & & \\
\hline & Житомирська & 13 & & $\begin{array}{l}240,0- \\
1027,0\end{array}$ & - \\
\hline & Чернігівська & 2 & & - & $130,0-166,5$ \\
\hline Зерно & Всього: & $1 /-$ & $50 / 20$ & & \\
\hline & Рівненська & 1 & & 289,0 & - \\
\hline Корми & Всього: & $41 / 8$ & $600 / 100$ & & \\
\hline & Волинська & 16 & & $721,2-790,4$ & - \\
\hline & Житомирська & 4 & & $\begin{array}{l}803,0- \\
2248,0\end{array}$ & - \\
\hline & Київська & 8 & & - & $113,8-332,9$ \\
\hline & Рівненська & 21 & & $\begin{array}{l}618,0- \\
1486,0\end{array}$ & 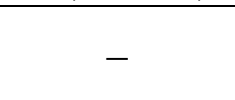 \\
\hline
\end{tabular}

Як видно з таблиці, найбільша кількість перевищень МДР зафіксовано за вмістом радіоізотопу ${ }^{137} \mathrm{Cs}$ у свіжих грибах та ягодах (1191 зразок: мin-max 503,0-31880,0 Бк/кг), грибах та ягодах сухих (533 зразки: мin-max 2518-65320 Бк/кг), молоці ВРX (624 зразки: мin-max 101,0-919,0 Бк/л), м'ясі диких тварин (335 зразків: мin-max 405,2-51455,0 Бк/кг) та городній зелені (102 зразки: мin$\max 41,6-138,0$ Бк/кг).

Перевищення МДР за вмістом радіоізотопу ${ }^{90} \mathrm{Sr}$ мали поодинокий характер і були виявлені в кормах (8 зразків: мin-max 113,8-332,9 Бк/кг) та лікарських рослинах (2 зразки: мin-max 130,0-166,5 Бк/кг) [3].

Риба, мед, зерно, корми та м'ясо ВРХ були найменш забрудненими радіоактивним цезієм серед проаналізованих видів продукції - їх частка від загальної кількості перевищень складала не більше $1 \%$.

3 таблиці 1 видно, що перевищення МДР вмісту радіоізотопів стабільно фіксують у Житомирській, Волинській, Рівненській, Чернігівській, Київській областях (по кількості перевищень області розташовані від більшого до меншого). Значно менше перевищень було виявлено в Сумській та Львівській областях.

На рисунку 1 наведено співвідношення забрудненості цезієм-137 різних видів продукції за 2013-2017 роки. 


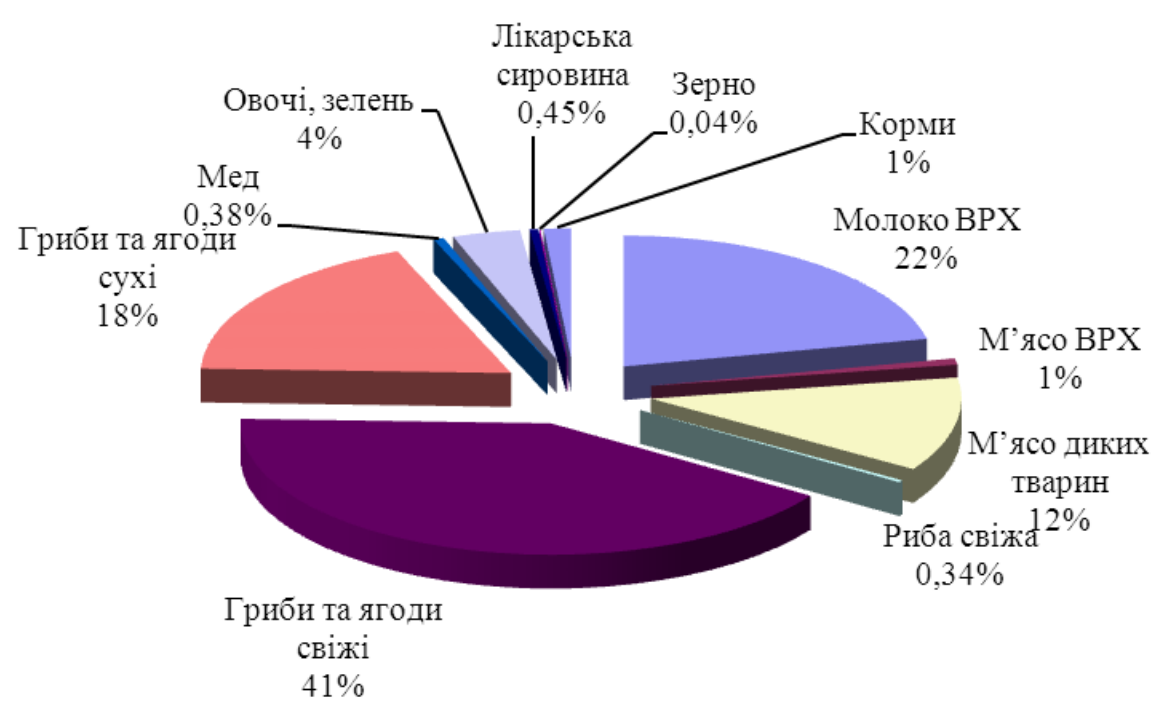

\section{Рис. 1. Співвідношення забрудненості цезієм-137 різних видів продукції за період 2013-2017 роки}

3 даних табл. 1 та рис. 1 зроблено висновок: зелень, яка має $4 \%$ перевищень, займає незначну частку раціону населення; дари лісу складають $59 \%$ перевищень, це велика частка, але, враховуючи, що дари лісу не $є$ основною частиною раціону населення, було вирішено зупинитися на вивченні тенденцій забруднення молока ВРХ в Україні, яке має $22 \%$ перевищень, та проаналізувати ступінь забруднення харчових продуктів і кормів радіоцезієм, як основного дозоутворюючого ізотопа, у найбільш забрудненій Житомирській області.

Для аналізу динаміки забруднення молока ВРХ були взяті два періоди 3 2000 по 2004 та з 2013 по 2017 роки. Метою аналізу було порівняти ці два періоди та оцінити динаміку забруднення вказаного продукту за досить тривалий період з 2000 по 2017 рік.

Встановлено, що за період 32000 по 2004 роки лабораторіями Держпродспоживслужби на вміст цезію-137 та стронцію-90 було проведено 10866351 досліджень різних видів продукції, з них перевищень МДР по двох нуклідах за вказаний період зафіксовано - 9374 [4].

Кількість перевищень цезію-137 у молоці великої рогатої худоби по забрудненим областям показано у таблиці 2 .

3 таблиці 2 видно, що молоко ВРХ було забруднено тільки цезієм-137. Перевищення МДР у молоці виявили лише в п'яти областях: Київській, Житомирській, Волинській, Чернігівській та Рівненській. Частка молока від усіх продуктів, у яких виявили перевищення (9374 зразки), склала 24,6 \% (2301 зразок). 
Частка зразків продукції з перевищенням ${ }^{137} \mathrm{Cs}$ по областях за період 2000-2004 pp.

\begin{tabular}{|c|c|c|c|c|c|c|c|}
\hline \multirow[b]{2}{*}{$\underline{\theta}$} & \multirow{2}{*}{ 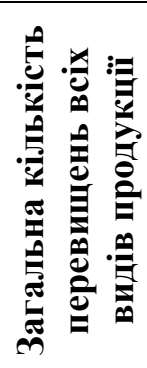 } & \multirow[b]{2}{*}{ 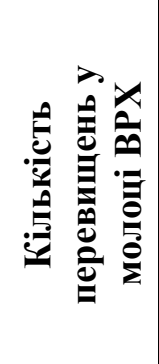 } & \multicolumn{5}{|c|}{$\begin{array}{c}\text { Кількість перевищень у молоці великої рогатої худоби } \\
\text { по областях }\end{array}$} \\
\hline & & & 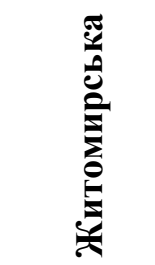 & 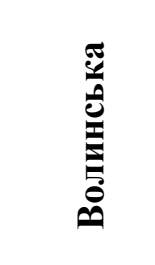 & 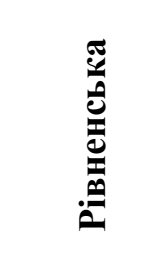 & 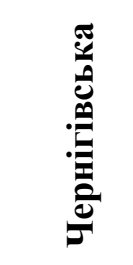 & 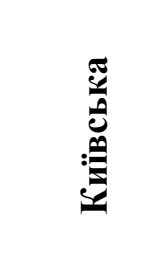 \\
\hline 2000 & 1825 & 543 & 152 & 13 & 254 & 124 & - \\
\hline 2001 & 2280 & 228 & 117 & 69 & 18 & 18 & - \\
\hline 2002 & 1925 & 677 & 162 & 133 & 380 & 7 & 1 \\
\hline 2003 & 1712 & 438 & 187 & 39 & 210 & 2 & - \\
\hline 2004 & 1632 & 415 & 129 & 48 & 190 & 47 & 1 \\
\hline Всього & $\begin{array}{c}9374 \\
(100 \%)\end{array}$ & $\begin{array}{c}2301 \\
(24,6 \%)\end{array}$ & $\begin{array}{c}747 \\
(32,4 \%)\end{array}$ & $\begin{array}{c}302 \\
(13,1 \%)\end{array}$ & $\begin{array}{c}1052 \\
(45,6 \%)\end{array}$ & $\begin{array}{c}198 \\
(8,6 \%)\end{array}$ & $\begin{array}{c}2 \\
(0,08 \%)\end{array}$ \\
\hline
\end{tabular}

В період з 2013 по 2017 роки на вміст ${ }^{137} \mathrm{Cs}$ та ${ }^{90} \mathrm{Sr}$ проведено 8627385 радіологічних досліджень, з них перевищення МДР встановлено у 2570 зразках порівняно з 9374 зразками за період 2000-2004 роки. Таким чином, частота виявлення забрудненої продукції з 2013 по 2017 рр. порівняно з періодом 3 2000-2004 pp. зменшилась утричі - з 0,09 \% до 0,03 \%. Дані щодо перевищень, виявлених у період 2013-2017 роки, вказано у таблиці 3.

Таблиия 3

Частка зразків 3 перевищенням вмісту ${ }^{137} \mathrm{Cs}$ по областях у період з 2013 по 2017 рp.

\begin{tabular}{|c|c|c|c|c|c|}
\hline \multirow{2}{*}{ Рік } & \multirow{2}{*}{$\begin{array}{c}\text { Загальна } \\
\text { кількість } \\
\text { перевищень } \\
\text { всіх видів } \\
\text { продукції } \\
\end{array}$} & \multirow{2}{*}{$\begin{array}{c}\text { Кількість } \\
\text { перевищень } \\
\text { у молоці } \\
\text { ВРX }\end{array}$} & \multicolumn{3}{|c|}{$\begin{array}{c}\text { Кількість перевищень у молоці великої } \\
\text { рогатої худоби по областях }\end{array}$} \\
\hline & & & Житомирська & Волинська & Рівненська \\
\hline 2013 & 690 & 189 & 101 & 4 & 84 \\
\hline 2014 & 480 & 151 & 76 & 4 & 71 \\
\hline 2015 & 466 & 117 & 78 & 3 & 36 \\
\hline 2016 & 378 & 75 & 62 & 4 & 9 \\
\hline 2017 & 556 & 71 & 57 & 9 & 5 \\
\hline Всього & $2570(100 \%)$ & $603(23,5 \%)$ & $374(62 \%)$ & $24(4 \%)$ & $205(34 \%)$ \\
\hline
\end{tabular}

Отже, як зазначено в таблиці 3, практично всі випадки - це перевищення радіоцезію. Частка молока 3 них складає - 23,5\% (603 зразки) порівняно 3 періодом 2000 по 2004 роки - 24,6\% (2301зразок). При цьому кількість областей, де фіксували забрудненість молока вище МДР, скоротилася з п'яти до трьох. Максимальна кількість перевищень у молоці була у Житомирській області - $62 \%$, дещо менше у Рівненській $-34 \%$, у Волинській лише $4 \%$ 
(табл. 3). У Київській та Чернігівській областях не зафіксовано жодного випадку підвищеного рівня забруднення молока радіонуклідами.

Варто зазначити, що з роками прослідковується чітка тенденція до зменшення кількості зразків молока 3 перевищеним вмістом радіоцезію. Зокрема у Житомирській області у 2017 році кількість випадків перевищення МДР цезію в молоці зменшилась у два рази, порівняно із 2013, а у Рівненській - майже у 17 разів. Основний фактор поліпшення якості молока за вмістом радіонуклідів - $є$ природній розпад радіоактивних ізотопів. Інший, не менш вагомий фактор - проведення агротехнічних заходів і зміна типу годівлі тварин.

Також було проаналізовано результати досліджень щодо визначення вмісту основного дозоутворюючого радіонукліду ${ }^{137} \mathrm{Cs}$ в харчових продуктах тваринного, рослинного походження та кормах, наданих лабораторіями Держпродспоживслужби Житомирської області, як найбільш забрудненої, за період 2013-2017 рр. (табл. 4).

Таблиия 4

Кількість перевищень допустимих рівнів питомої активності радіонукліду ${ }^{137}$ Cs в харчових продуктах та кормах

у Житомирській області за період 2013-2017 рр.

\begin{tabular}{|c|c|c|c|c|c|c|c|c|}
\hline \multirow[b]{2}{*}{$\begin{array}{c}\text { Назва } \\
\text { району }\end{array}$} & \multirow[b]{2}{*}{$\begin{array}{c}\text { Назва } \\
\text { показника }\end{array}$} & \multicolumn{7}{|c|}{ Вид продукції } \\
\hline & & 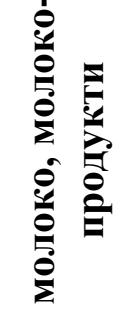 & 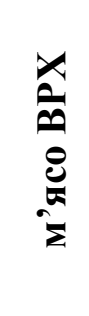 & 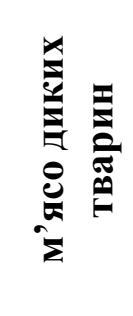 & 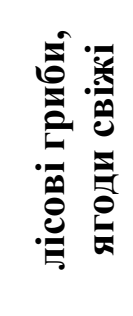 & 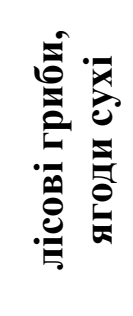 & $\stackrel{5}{\stackrel{5}{2}}$ & 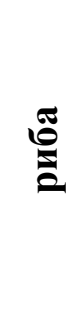 \\
\hline 1 & 2 & 3 & 4 & 5 & 6 & 7 & 8 & 9 \\
\hline \multicolumn{9}{|c|}{2013} \\
\hline \multirow{2}{*}{$\begin{array}{c}\text { Коростен- } \\
\text { ський }\end{array}$} & кількість проб & - & 1 & - & - & - & - & - \\
\hline & $\begin{array}{l}\text { активність min- } \\
\max \end{array}$ & - & 340 & - & - & - & - & - \\
\hline \multirow[b]{2}{*}{ Малинський } & кількість проб & - & - & 8 & 4 & 1 & - & - \\
\hline & $\begin{array}{c}\text { активність min- } \\
\max \end{array}$ & - & - & $\begin{array}{l}633- \\
5450 \\
\end{array}$ & $\begin{array}{l}521- \\
2320 \\
\end{array}$ & 3750 & - & - \\
\hline \multirow[b]{2}{*}{ Народицький } & кількість проб & 64 & - & 2 & 45 & 7 & - & 1 \\
\hline & $\begin{array}{c}\text { активність min- } \\
\max \end{array}$ & $\begin{array}{l}111- \\
293\end{array}$ & - & $\begin{array}{c}1149- \\
7600\end{array}$ & $\begin{array}{c}567- \\
27500\end{array}$ & $\begin{array}{l}5849- \\
42625\end{array}$ & - & $\begin{array}{c}18 \\
4\end{array}$ \\
\hline \multirow[b]{2}{*}{ Овруцький } & кількість проб & - & - & 3 & 28 & 19 & 1 & - \\
\hline & $\begin{array}{c}\text { активність min- } \\
\max \end{array}$ & - & - & $\begin{array}{l}475- \\
2105\end{array}$ & $\begin{array}{l}570- \\
7120\end{array}$ & $\begin{array}{c}2700- \\
6000\end{array}$ & 370 & - \\
\hline
\end{tabular}




\begin{tabular}{|c|c|c|c|c|c|c|c|c|}
\hline & & & & & & Іродовжен & ия таб. & uụi 4 \\
\hline 1 & 2 & 3 & 4 & 5 & 6 & 7 & $8 \mid$ & 9 \\
\hline & кількість проб & 4 & - & - & - & - & - & - \\
\hline Олевський & $\begin{array}{c}\text { активність } \\
\text { min-max }\end{array}$ & $\begin{array}{c}112- \\
120\end{array}$ & - & - & - & - & - & - \\
\hline & кількість проб & 16 & - & - & 7 & 1 & - & - \\
\hline Лугинський & $\begin{array}{c}\text { активність } \\
\text { min-max }\end{array}$ & $\begin{array}{c}103- \\
434\end{array}$ & - & - & $\begin{array}{l}609- \\
1840\end{array}$ & 4200 & - & - \\
\hline & кількість проб & - & - & - & 4 & 1 & - & - \\
\hline $\begin{array}{l}\text { Новоград- } \\
\text { Волинський }\end{array}$ & $\begin{array}{c}\text { активність } \\
\min -\max \end{array}$ & - & - & - & $\begin{array}{l}610- \\
1010\end{array}$ & 3519 & - & - \\
\hline & кількість проб & - & - & - & 15 & 8 & - & - \\
\hline Ємільчинський & $\begin{array}{c}\text { активність } \\
\text { min-max }\end{array}$ & - & - & - & $\begin{array}{l}508- \\
3050 \\
\end{array}$ & $\begin{array}{l}5223- \\
10280 \\
\end{array}$ & - & - \\
\hline & & & 2014 & & & & & \\
\hline & кількість проб & 1 & - & - & - & - & - & - \\
\hline Коростенський & $\begin{array}{c}\text { активність } \\
\min -\max \end{array}$ & 102 & - & - & - & - & - & - \\
\hline & кількість проб & - & - & 11 & - & 1 & - & - \\
\hline Малинський & $\begin{array}{c}\text { активність } \\
\text { min-max }\end{array}$ & - & - & $\begin{array}{c}409- \\
18500\end{array}$ & - & 3500 & - & - \\
\hline & кількість проб & 64 & - & 11 & 42 & 3 & - & 1 \\
\hline Народицький & $\begin{array}{c}\text { активність } \\
\text { min-max }\end{array}$ & $\begin{array}{c}109- \\
220\end{array}$ & - & $\begin{array}{c}1428- \\
6000\end{array}$ & $\begin{array}{l}584- \\
4745\end{array}$ & $\begin{array}{c}5437- \\
7126\end{array}$ & - & 189 \\
\hline & кількість проб & - & - & 1 & 29 & 17 & - & - \\
\hline Овруцький & $\begin{array}{c}\text { активність } \\
\text { min-max }\end{array}$ & - & - & 4070 & $\begin{array}{l}528- \\
6300\end{array}$ & $\begin{array}{c}2580- \\
4000\end{array}$ & - & - \\
\hline & кількість проб & - & - & 1 & - & 2 & - & - \\
\hline Олевський & $\begin{array}{c}\text { активність } \\
\min -\max \end{array}$ & - & - & 2069 & - & $\begin{array}{c}3500- \\
4159\end{array}$ & - & - \\
\hline & кількість проб & 5 & - & 7 & 6 & 2 & - & - \\
\hline Лугинський & $\begin{array}{c}\text { активність } \\
\text { min-max }\end{array}$ & $\begin{array}{l}106- \\
259\end{array}$ & - & $\begin{array}{c}463- \\
14700\end{array}$ & $\begin{array}{l}580- \\
2610\end{array}$ & $\begin{array}{c}5945- \\
7540\end{array}$ & - & - \\
\hline & кількість проб & - & - & - & - & 1 & - & - \\
\hline Волинський & $\begin{array}{c}\text { активність } \\
\text { min-max }\end{array}$ & - & - & - & - & 2590 & - & - \\
\hline & кількість проб & - & - & - & 3 & 14 & - & - \\
\hline Ємільчинський & $\begin{array}{c}\text { активність } \\
\text { min-max }\end{array}$ & - & - & - & $\begin{array}{c}650- \\
731\end{array}$ & $\begin{array}{c}3091- \\
6416\end{array}$ & - & - \\
\hline & & & 2015 & & & & & \\
\hline & кількість проб & 2 & - & - & - & - & - & - \\
\hline Коростенський & $\begin{array}{c}\text { активність } \\
\min -\max \end{array}$ & $\begin{array}{c}126- \\
146 \\
\end{array}$ & - & - & - & - & - & - \\
\hline & кількість проб & - & - & 5 & 2 & - & - & - \\
\hline Малинський & $\begin{array}{c}\text { активність } \\
\text { min-max }\end{array}$ & - & - & $\begin{array}{l}525- \\
1650\end{array}$ & $\begin{array}{c}801- \\
809\end{array}$ & - & - & - \\
\hline & кількість проб & 58 & - & 9 & 45 & 5 & 3 & 1 \\
\hline Народицький & $\begin{array}{c}\text { активність } \\
\text { min-max }\end{array}$ & $\begin{array}{c}101- \\
186\end{array}$ & - & $\begin{array}{l}1379 \\
51455\end{array}$ & $\begin{array}{l}512- \\
4146\end{array}$ & $\begin{array}{l}5429- \\
24467\end{array}$ & $\begin{array}{c}273- \\
539\end{array}$ & 184 \\
\hline
\end{tabular}


Продовження таблищ̧і 4

\begin{tabular}{|c|c|c|c|c|c|c|c|c|}
\hline 1 & 2 & 3 & 4 & 5 & 6 & 7 & 8 & 9 \\
\hline \multirow[b]{2}{*}{ Овруцький } & кількість проб & 1 & - & 14 & 18 & 15 & 2 & - \\
\hline & $\begin{array}{c}\text { активність } \\
\text { min-max }\end{array}$ & 130 & - & $\begin{array}{c}470- \\
39600\end{array}$ & $\begin{array}{l}572- \\
1010\end{array}$ & $\begin{array}{c}2664- \\
3000\end{array}$ & $\begin{array}{c}250- \\
370\end{array}$ & - \\
\hline \multirow[b]{2}{*}{ Олевський } & кількість проб & - & - & 2 & 1 & 1 & - & - \\
\hline & $\begin{array}{c}\text { активність } \\
\min -\max \end{array}$ & - & - & $\begin{array}{l}750- \\
1000\end{array}$ & 740 & 2950 & - & - \\
\hline \multirow[b]{2}{*}{ Лугинський } & кількість проб & 8 & - & 3 & 5 & 3 & - & - \\
\hline & $\begin{array}{c}\text { активність } \\
\text { min-max } \\
\end{array}$ & $\begin{array}{c}119- \\
272 \\
\end{array}$ & - & $\begin{array}{c}563- \\
13800\end{array}$ & $\begin{array}{l}891- \\
3840\end{array}$ & $\begin{array}{c}3233- \\
3951\end{array}$ & - & - \\
\hline \multirow{2}{*}{$\begin{array}{l}\text { Новоград- } \\
\text { Волинський }\end{array}$} & кількість проб & - & - & - & 2 & - & - & - \\
\hline & $\begin{array}{c}\text { активність } \\
\text { min-max }\end{array}$ & - & - & - & $863-948$ & - & - & - \\
\hline \multirow[b]{2}{*}{ Ємільчинський } & кількість проб & - & - & - & 2 & 8 & - & - \\
\hline & $\begin{array}{c}\text { активність } \\
\text { min-max }\end{array}$ & - & - & - & $650-659$ & $\begin{array}{c}3208- \\
5498\end{array}$ & - & - \\
\hline \multicolumn{9}{|c|}{2016} \\
\hline \multirow[b]{2}{*}{ Коростенський } & кількість проб & - & - & - & - & - & - & - \\
\hline & $\begin{array}{l}\text { активність min- } \\
\max \end{array}$ & - & - & - & - & - & - & - \\
\hline \multirow[t]{2}{*}{ Малинський } & кількість проб & - & - & - & 1 & - & - & - \\
\hline & $\begin{array}{c}\text { активність min- } \\
\text { max }\end{array}$ & - & - & - & 1172 & - & - & - \\
\hline \multirow[b]{2}{*}{ Народицький } & кількість проб & 60 & - & 9 & 50 & 1 & - & 1 \\
\hline & $\begin{array}{l}\text { активність min- } \\
\text { max }\end{array}$ & $\begin{array}{c}103- \\
165 \\
\end{array}$ & - & $\begin{array}{c}1852- \\
3547 \\
\end{array}$ & $\begin{array}{l}511- \\
7200\end{array}$ & 16372 & - & 187 \\
\hline \multirow[b]{2}{*}{ Овруцький } & кількість проб & - & - & 2 & 29 & 11 & - & - \\
\hline & $\begin{array}{l}\text { активність min- } \\
\max \end{array}$ & - & - & $\begin{array}{l}800- \\
1918\end{array}$ & $\begin{array}{l}560- \\
1815\end{array}$ & $\begin{array}{c}2570- \\
3105\end{array}$ & - & - \\
\hline \multirow[b]{2}{*}{ Олевський } & кількість проб & 1 & - & 9 & - & - & - & - \\
\hline & $\begin{array}{c}\text { активність min- } \\
\text { max }\end{array}$ & 107 & - & 1700 & - & - & - & - \\
\hline \multirow[b]{2}{*}{ Лугинський } & кількість проб & - & - & 3 & 8 & - & - & - \\
\hline & $\begin{array}{l}\text { активність min- } \\
\text { max }\end{array}$ & - & - & $\begin{array}{l}750- \\
4900 \\
\end{array}$ & $\begin{array}{l}518- \\
1760 \\
\end{array}$ & - & - & - \\
\hline \multirow{2}{*}{$\begin{array}{l}\text { Новоград- } \\
\text { Волинський }\end{array}$} & кількість проб & - & - & - & - & 1 & - & - \\
\hline & $\begin{array}{c}\text { активність } \min - \\
\max \end{array}$ & - & - & - & - & 2920 & - & - \\
\hline \multirow[b]{2}{*}{ Смільчинський } & кількість проб & - & - & - & 4 & 7 & - & - \\
\hline & $\begin{array}{l}\text { активність min- } \\
\text { max }\end{array}$ & - & - & - & $594-861$ & $\begin{array}{c}2720- \\
4928\end{array}$ & - & - \\
\hline \multicolumn{9}{|c|}{2017} \\
\hline \multirow[b]{2}{*}{ Коростенський } & кількість проб & - & - & - & - & - & - & - \\
\hline & $\begin{array}{l}\text { активність min- } \\
\max \end{array}$ & - & - & - & - & - & - & - \\
\hline \multirow[b]{2}{*}{ Малинський } & кількість проб & - & - & 3 & 1 & 2 & - & - \\
\hline & $\begin{array}{c}\text { активність min- } \\
\text { max }\end{array}$ & - & - & $\begin{array}{l}551- \\
2550 \\
\end{array}$ & 623 & $\begin{array}{l}2750- \\
11455 \\
\end{array}$ & - & - \\
\hline
\end{tabular}




\begin{tabular}{|c|c|c|c|c|c|c|c|c|}
\hline \multicolumn{9}{|c|}{ Продовження таблии̧і 4} \\
\hline 1 & 2 & 3 & 4 & 5 & 6 & 7 & 8 & 9 \\
\hline \multirow[b]{2}{*}{ Народицький } & кількість проб & 57 & - & 6 & 55 & 1 & 2 & - \\
\hline & $\begin{array}{l}\text { активність min- } \\
\text { max }\end{array}$ & $\begin{array}{c}102- \\
188 \\
\end{array}$ & - & $\begin{array}{l}412- \\
2243 \\
\end{array}$ & $\begin{array}{l}570- \\
4000 \\
\end{array}$ & 2768 & $\begin{array}{c}234- \\
370 \\
\end{array}$ & - \\
\hline \multirow[b]{2}{*}{ Овруцький } & кількість проб & - & - & - & 30 & 13 & 3 & - \\
\hline & $\begin{array}{l}\text { активність min- } \\
\text { max }\end{array}$ & - & - & - & $\begin{array}{l}520- \\
7300 \\
\end{array}$ & $\begin{array}{c}2650- \\
7500\end{array}$ & $\begin{array}{c}562- \\
830 \\
\end{array}$ & - \\
\hline \multirow[b]{2}{*}{ Олевський } & кількість проб & - & - & 1 & 2 & - & - & - \\
\hline & $\begin{array}{l}\text { активність min- } \\
\text { max }\end{array}$ & - & - & 2059 & $\begin{array}{l}814- \\
1376\end{array}$ & - & - & - \\
\hline \multirow[b]{2}{*}{ Лугинський } & кількість проб & - & - & 1 & 6 & - & - & - \\
\hline & $\begin{array}{l}\text { активність min- } \\
\text { max }\end{array}$ & - & - & 531 & $\begin{array}{l}691- \\
1280\end{array}$ & - & - & - \\
\hline \multirow{2}{*}{$\begin{array}{l}\text { Новоград- } \\
\text { Волинський }\end{array}$} & кількість проб & - & - & - & 7 & - & - & - \\
\hline & $\begin{array}{c}\text { активність min- } \\
\max \\
\end{array}$ & - & - & - & $602-794$ & - & - & - \\
\hline \multirow[b]{2}{*}{ Смільчинський } & кількість проб & - & - & - & 8 & 6 & - & - \\
\hline & $\begin{array}{l}\text { активність min- } \\
\text { max }\end{array}$ & - & - & - & $\begin{array}{l}515- \\
1321\end{array}$ & $\begin{array}{c}2636- \\
3280\end{array}$ & - & - \\
\hline $\begin{array}{c}\text { Загальна } \\
\text { кількість } \\
\text { перевищень }\end{array}$ & & 341 & 1 & 111 & 459 & 151 & 11 & 4 \\
\hline
\end{tabular}

У Житомирській області у 2013-2017 рр. найбільша кількість перевищень припадала на лісову продукцію (лісові гриби та ягоди, м'ясо диких тварин) та молоко ВРX [5].

\section{Висновки та перспективи подальших досліджень:}

1. Значна роль у формуванні дози внутрішнього опромінення населення в Україні належить цезію-137.

2. Визначено критичні за радіологічними показниками харчові продукти - це молоко ВРХ та дари лісу (лісові гриби та ягоди, м'ясо диких тварин). В зоні Полісся ці продукти складають значну частку раціону населення регіону. Їх рівні забруднення перевищували допустимі у 2-3, а іноді у 4-6 разів.

3. Серед областей України найбільш неблагополучними за вмістом ${ }^{137} \mathrm{Cs}$ в молоці є Житомирська, Волинська і Рівненська області. Київську, Чернігівську області можна віднести до відносно чистих по молоку.

4. Мета майбутніх напрямів роботи - підвищення рівня вивчення та знання радіаційної ситуації в Україні.

\section{СПИСОК ЛІТЕРАТУРИ}

1. Малиновський А.С. Системне відродження територій в регіоні радіаційного забруднення / А.С. Малиновський. - К.: ННЦ «Інститут аграрної економіки», 2007. - С. 75-102.

2. Романченко К.М., Малімон 3.В., Прокопенко Т.О., Гусак Л.М., Кірєєва О.Г., Молодик А.Г. та ін. Аналіз забрудненості харчових продуктів радіонуклідами на території України за період 2013-2017 років / Чорнобильська катастрофа. Актуальні проблеми, напрямки та шляхи їх вирішення : міжнародна науково-практична конференція (26-27 квітня 2018 року). - Житомир : ЖНАЕУ, 2018. - С. 251-255. 
3. Малімон 3.В. Забрудненість об’єктів ветеринарного нагляду радіонуклідами ${ }^{137} \mathrm{Cs}$ i ${ }^{90} \mathrm{Sr}$ в Україні за 2012-2017 роки / 3.В. Малімон, Т.О. Прокопенко, Л.М. Гусак, А.Г. Молодик // Ветеринарна медицина. - 2018. - Вип. 104. - С. 263-267.

4. Прокопенко Т.О., Носевич Д.К., Малімон 3.В., Носевич О.В., Кірєєва О.Г., Молодик А.Г. та ін. Динаміка забруднення молока великої рогатої худоби ${ }^{137} \mathrm{Cs}$ в Україні у період 3 2000 по 2017 роки / Чорнобильська катастрофа. Актуальні проблеми, напрямки та шляхи їх вирішення : міжнародна науково-практична конференція (26-27 квітня 2018 року). Житомир : ЖНАЕУ, 2018. - С. 245-250.

5. Гусак Л.М., Малімон 3.В., Прокопенко Т.О., Давиденко Л.М, Музиченко О.В., Кірєєва О.Г. та ін. «Аналіз забруднення радіонуклідом цезій-137 основних видів харчових продуктів Житомирської області за період 2013-2017 роки / Чорнобильська катастрофа. Актуальні проблеми, напрямки та шляхи їх вирішення: міжнародна науково-практична конференція (26-27 квітня 2018 року). - Житомир : ЖНАЕУ, 2018. - С. 255-264.

\section{ОЦЕНКА РЕЗУЛЬТАТОВ ИССЛЕДОВАНИЯ РАДИАЦИОННОЙ} ЗАГРЯЗНЕННОСТИ ПИЩЕВЫХ ПРОДУКТОВ И КОРМОВ ЗА 2013-2017 ГОДЫ / Прокопенко Т.А., Малимон 3.В., Гусак Л.Н., Молодык А.Г.

Осуществлен анализ результатов исследований радиоактивного загрязнения пищевых продуктов и кормов, выполненных государственными лабораториями Госпотребслужбы в Украине за 2013-2017 г2. Определены критические дозообразующие пищевые продукты - молоко КРС и дары леса. Установлено, основная роль в формировании дозы внутреннего облучения принадлежит ${ }^{137}$ Cs. Проанализирована динамика загрязнения молока КРC с 2000 по 2017 годы. Наиболее неблагополучные по содержанию ${ }^{137}$ Cs в молоке Житомирская, Вольнская и Ровенская области. Киевская, Черниговская области относительно чистые по молоку. Изучены результаты исследований по содержанию ${ }^{137}$ Cs 8 пищевых продуктах и кормах в Житомирской области.

Ключевые слова: радиологический контроль, динамика загрязнения, радиоизотопь, пищевые продукты, корма.

\section{EVALUATION OF THE RESULTS OF THE RADIATION POLLUTION OF FOOD} AND FEED IN 2013-2017 / Prokopenko T.O., Malimon Z.V., Gusak L.M., Molodik A.G.

Introduction. Veterinary radiological control is a type of environmental radioecological monitoring. ${ }^{137} \mathrm{Cs}$ and ${ }^{90} \mathrm{Sr}$ are the most biologically significant contaminants during the recovery period in case of emergency, veterinary radiological control is aimed at identification of these indicators.

The goal of the work. Analysis of data on the content of radioisotopes in food and feed. Analyze the radiation situation in the regions of Ukraine in relation to food and feed for the period from 2013 to 2017. Identify critical dose-forming food.

Materials and methods. Statistical and analytical method of veterinary reporting in radiology departments of the State Laboratories of The State Service for Food Safety and Consumer Protection of Ukraine in 2013-2017. $\gamma-\beta$-spectrometric method for determining the content of radionuclides.

Results of resesrch and discussion:

1). Zhytomyr, Volyn, Rivne, Kyiv and Chernihiv oblasts remain the most contaminated areas.

2). The frequency of detection of contaminated products decreased from $0.09 \%$ to $0.03 \%$ in the periods from 2000-2004 to 2013-2017.

3). The major role in the formation of the radiation dose in Ukraine is attributed to ${ }^{137} \mathrm{Cs}$ (forest mushrooms and berry, bovine milk and meat from wild animals. 
Conclusions and prospects for further research. The major role in the formation of the radiation dose in Ukraine is attributed to 137Cs (forest mushrooms and berry, bovine milk and meat from wild animals). Zhytomyr, Volyn, Rivne, Kyiv and Chernihiv Oblasts are the most contaminated areas. situation.

The purpose of future directions - raising the level of study and knowledge of the radiation

Keywords: radiological control, dynamics of pollution, radioisotopes, food products, feed.

\section{REFERENCES}

1. Malynovs'kyj, A.S. (2007). Systemne vidrodzhennja terytorij v regioni radiacijnogo zabrudnennja [Systemic revival of territories in the region of radiation contamination]. - K.: NNC «Instytut agrarnoi ekonomiky» [in Ukranian].

2. Romanchenko, K.M., Malimon, Z.V., Prokopenko, T.O., Gusak, L.M. Kire€va, O.G., Molodik A.G. et al. (2018). Analiz zabrudnenosti harchovih produktiv radionuklidami na teritorii Ukraini za period 2013-2017 rokiv [Analysis of food contamination by radionuclides in Ukraine for 2013-2017]. Proceedings from The Chernobyl disaster. Actual problems, directions and ways of their solution '17: / Mizhnarodna naukovo-praktichna konferencija (26-27 kvitnja 2018 roku) International scientific and practical conference. (pp. 251-255). Zhitomir : ZHNAEU [in Ukranian].

3. Malimon, Z.V., Prokopenko, T.O., Gusak, L.M., \& Molodik, A.G. (2018). Zabrudnenist obektiv veterinarnogo nagljadu radionuklidami 137Cs i 90Sr v Ukraini za 2012-2017 roki [Contamination of the objects of veterinary supervision with radionuclides $137 \mathrm{Cs}$ and $90 \mathrm{Sr}$ in Ukraine for 2012-2017]. Veterinarna medicina - Veterinary medicine, 104, 263-267 [in Ukranian].

4. Prokopenko, T.O., Nosevich, D.K., Malimon, Z.V., Nosevich, O.V., Kirjejeva, O.G., Molodik, A.G. et al. (2018). Dynamika zabrudnennja moloka velykoi' rogatoi' hudoby 137Cs v Ukraini u period z 2000 po 2017 roky [Dynamics of contamination of 137Cs bovine milk in Ukraine from 2000 to 2017]. Proceedings from The Chernobyl disaster. Actual problems, directions and ways of their solution '17: / Mizhnarodna naukovo-praktichna konferencija (26-27 kvitnja 2018 roku) International scientific and practical conference. (pp. 245-250). Zhitomir : ZHNAEU [in Ukranian].

5. Gusak, L.M., Malimon, Z.V., Prokopenko, T.O., Davidenko, L.M, Muzichenko, O.V., Kireeva, O.G. et al. (2018). Analiz zabrudnennja radionuklidom cezij-137 osnovnyh vydiv harchovyh produktiv Zhytomyrskoi oblasti za period 2013-2017 roky [Analysis of contamination by radionuclide cesium-137 of the main types of food products of Zhytomyr region for the period of 2013-2017 years]. Proceedings from The Chernobyl disaster. Actual problems, directions and ways of their solution '17: / Mizhnarodna naukovo-praktichna konferencija (26-27 kvitnja 2018 roku) International scientific and practical conference. (pp. 255-264). Zhitomir : ZHNAEU [in Ukranian]. 